\title{
Perbandingan Debit Andalan Hasil Tank Model terhadap Debit Pengamatan Sungai Tapung Kiri Stasiun Tandun
}

\author{
Fachrunnisa', Manyuk Fauzi ${ }^{2}$, Trimaijon ${ }^{3}$ \\ 1,2,3 Program Studi Teknik Sipil, Fakultas Teknik, Universitas Riau \\ Kampus Bina Widya Jl. HR Soebrantas KM 12,5 Pekanbaru, Kode Pos 28293 Telp. (0761) 52324 \\ Email: fachrunnisa.f@student.unri.ac.id, manyuk.fauzi@.unri.ac.id,
}

\begin{abstract}
ABSTRAK
Ketelitian suatu model hujan-aliran sangat dibutuhkan guna implementasi keluaran model dalam analisis-analisis hidrologi. Penelitian ini bertujuan untuk melakukan analisis terhadap rasio atau perbandingan hasil model tangki (tank model) terhadap data debit hasil pengamatan. Penelitian dilakukan di sungai Tapung Kiri dengan stasiun pencatatan Tandun. Luas daerah aliran sungai Tapung Kiri dengan titk kontrol (outlet) stasiun Tandun adalah 197,5 km². Konsep model tangki yang digunakan adalah 4 buah tangki yang disusun secara seri. Hasil perbandingan didasarkan pada nilai root mean square error (RMSE), dimana diperoleh nilai RMSE kondisi musim basah $\left(\mathrm{Q}_{20 \%}\right)=6,70$; kondisi normal $\left(\mathrm{Q}_{50 \%}\right)=4,49$ dan musim kering $\left(\mathrm{Q}_{80 \%}\right)=5,27$. Data debit pengamatan sungai Tapung Kiri rata-rata memiliki nilai tempat satuan, sementara itu nilai RMSE juga memiliki nilai tempat satuan maka dapat disimpulkan bahwa model tangki yang digunakan dalam penelitian ini memiliki kinerja baik.
\end{abstract}

Kata kunci : debit andalan, model tangki, root mean square error, tapung kiri

\section{ABSTRACT}

The accuracy of a rainfall-runoff model is needed to implement the model output in hydrological analyzes. The aim study is to analyze of comparison between output of tank model and observed data. The study was conducted in the Tapung Kiri river with a Tandun water lever recording station. The area of the Tapung Kiri river basin with a Tandun station outlet is $197.5 \mathrm{~km}^{2}$. The tank model concept used is 4 tanks arranged in series. The results of the comparison are based on the value of root mean square error (RMSE), which obtained the value of RMSE wet season conditions $\left(\mathrm{Q}_{20 \%}\right)=6.70$; normal conditions $\left(\mathrm{Q}_{50 \%}\right)=4.49$ and dry season $\left(\mathrm{Q}_{80 \%}\right)=5.27$. Based on the value of root mean square error (RMSE), the performance of the model can be concluded to have good performance.

Keywords: dependable flow, tank model, root mean square error, tapung kiri

\section{PENDAHULUAN}

Riau adalah salah satu provinsi yang dialiri oleh empat sungai besar salah satunya adalah Sungai Siak. Sungai Siak merupakan sungai dengan palung yang terdalam di Indonesia, yaitu dengan kedalaman sekitar 20-30 meter yang panjang sungai mencapai 300 kilometer dengan melewati wilayah administrasi meliputi empat kabupaten dan satu kota. Wilayah administrasi tersebut yaitu Kabupaten Rokan Hulu, Kabupaten Bengkalis, Kabupaten Siak, Kabupaten Kampar dan Kota Pekanbaru. Dengan demikian dapat dikatakan bahwa Daerah Aliran Sungai (DAS) Siak sepenuhnya berada di Provinsi Riau.

Pesatnya perkembangan penduduk membuat penggunaan air juga meningkat, tidak hanya sebagai kebutuhan pokok atau domestik namun juga digunakan untuk berbagai sektor usaha seperti irigasi pertanian, peternakan dan lainnya. Kebutuhan air yang terus meningkat seiring pertumbuhan penduduk, menyebabkan tidak sejalannya antara kebutuhan dan ketersediaan air baik volume, waktu dan tempat tertentu. Pada saat ini kebutuhan air mungkin dapat terpenuhi, namun untuk masa yang akan datang ketersediaan air menjadi faktor penentu dalam pendistribusian air dan dapat berakibat terjadinya krisis air

Berdasarkan keadaan tersebut, maka diperlukan suatu studi untuk melihat keseimbangan antara ketersediaan dan penggunaan air sehingga nantinya kebutuhan air di daerah tersebut akan terus terpenuhi dari waktu ke waktu. Studi yang dapat dilakukan 
yaitu menggunakan model hidrologi untuk keperluan analisis tentang keberadaan air menurut aspek jumlah, waktu, tempat dan probabilitas. Model hidrologi memiliki banyak manfaat, salah satunya dapat digunakan untuk prediksi atau peramalan debit.

Model yang muncul saat ini adalah hasil pengembangan dari model terdahulu, beberapa pendekatan digunakan untuk membangun suatu permodelan curah hujan menjadi debit aliran sungai. Tank Model merupakan salah satu metode untuk transformasi (pengalihragaman) hujan-debit. Penelitian dengan judul "Simulasi Jumlah Tangki dan Susunannya dalam Analisis Run-off dengan Metode Tank Model" pada tahun 2000 di daerah aliran sungai (DAS) Bendo didapatkan bahwa susunan Tank Model yang paling tepat adalah Tank Model 4 tangki rangkaian seri.

Tank Model atau model tangki diperkenalkan oleh Dr. M. Sugawara yang menirukan (simulate) daerah aliran sungai dengan menggantikannya oleh sejumlah tampungan berupa sederet tangki. Tangki tersebut memiliki lubang di dinding tangki dan di dasar tangki. Aliran yang melewati lubanglubang yang berada di dinding tangki-tangki yang bersangkutan akan menghasilkan limpasan, sedangkan aliran yang melewati dasar tangki merupakan infiltrasi [1].

Setiawan menyebutkan secara global persamaan keseimbangan air Tank Model adalah sebagai berikut [2] :

$\frac{\mathrm{dH}}{\mathrm{dt}}=\mathrm{P}(\mathrm{t})-\mathrm{ET}(\mathrm{t})-\mathrm{Y}(\mathrm{t})$

dengan $H$ adalah tinggi air $(\mathrm{mm}), P(t)$ adalah hujan (mm/bulan), $E T(t)$ adalah evapotranspirasi $(\mathrm{mm} /$ bulan$), Y(t)$ adalah aliran total ( $\mathrm{mm} / \mathrm{bulan})$, dan $t$ adalah waktu (bulan).

Sebagai salah satu ilustrasi pemodelan konsep model tangki Sugawara, secara sederhana dapat dilihat pada Gambar 1 [3]. Ilustrasi tersebut menunjukkan proses di alam yang digambarkan dalam susunan tangki.
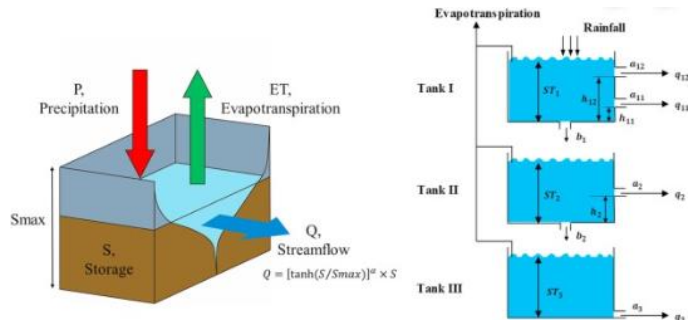

Gambar 1. Ilustrasi Model Tangki

Sementara itu, debit andalan (dependable flow) adalah besarnya debit yang tersedia di suatu lokasi sumber air untuk dapat dimanfaatkan dalam penyediaan air dengan risiko kegagalan yang telah diperhitungkan. Pengelolaan sumber daya air harus memperhatikan potensi sumber daya air yang ada. Potensi sumber daya air dalam konsep pengelolaan dibatasi oleh sistem alami yang dikenal sebagai wilayah sungai. Prediksi ketersediaan air di wilayah sungai sangat penting untuk pengelolaan air [4].

Ketersediaan air dinyatakan dalam debit andalan (dependable flow) atau debit minimum sungai yang kemungkinan terpenuhi $20 \%$ (kondisi musim basah, $\mathrm{Q}_{20 \%}$ ), 50\% (kondisi normal, $\mathrm{Q}_{50 \%}$ ), dan 80\% (kondisi musim kering, Q80\%) dan dihitung dengan metode Weibull [5] :

$\mathrm{P}=\frac{\mathrm{m}}{\mathrm{n}+1} \times 100 \%$

dengan $P$ adalah probabilitas terjadinya kumpulan nilai (debit) yang diharapkan (\%), $m$ adalah nomor urut kejadian, dengan urutan variasi dari besar ke kecil dan $n$ adalah jumlah data debit pengamatan.

Perbandingan debit andalan hasil model dan pengamatan dinilai berdasarkan nilai Root Mean Suare Error (RMSE). Nilai RMSE dapat dihitung menggunakan rumus:

$\mathrm{RMSE}=\sqrt{\frac{\sum(\mathrm{Qobs}-\mathrm{Q} \operatorname{sim})^{2}}{\mathrm{n}}}$

dengan Qobs adalah debit pengamatan (terukur), Qsim adalah debit keluaran Tank Model dan n adalah jumlah data.

Nilai RMSE dikehendaki mendekati nol.

\section{METODE PENELITIAN}

Penelitian ini dilakukan di daerah aliran sungai (DAS) Tapung Kiri bagian hulu dengan stasiun automatic water level recorder (AWLR) 
Tandun. Secara administrasi AWLR Tandun berada dalam wilayah kecamatan Tandun Kabupaten Rokan Hulu Provinsi Riau dengan letak geografis pada $00^{\circ} 35^{\prime} 41^{\prime \prime} \mathrm{LU} \quad 100^{\circ} 28^{\prime}$ 31 "BT. Luas pengairan DAS Tapung Kiri untuk AWLR Tandun adalah 197,5 $\mathrm{km}^{2}$. Menggunakan peta dari Badan Pengelola Daerah Aliran Sungai (BPDAS) Provinsi Riau, maka lokasi AWLR Tandun sebagaimana ditujukkan Gambar 2.

Data yang digunakan dalam penelitian ini meliputi data curah hujan, klimatologi dan debit yang diperoleh dari Balai Wilayah Sungai Sumatera III dengan rincian sebagai berikut:

a. Data curah hujan tahun 2007-2016 stasiun Petapahan Baru.

b. Data Klimatologi tahun 2007-2016 stasiun pengamatan Pekanbaru.

c. Data debit tahun 2007-2016 stasiun AWLR Tandun.

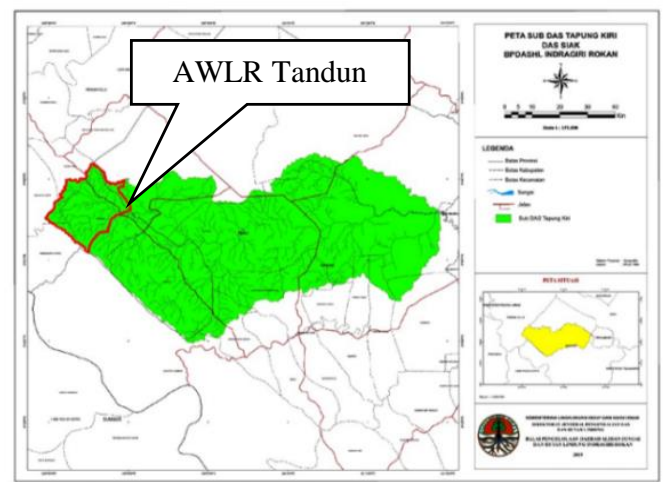

Gambar 2. Peta DAS Tapung Kiri Dengan Outlet AWLR Tandun

\section{HASIL DAN PEMBAHASAN}

Uji konsistensi data diperlukan untuk mengetahui kepanggahan data yang akan digunakan dalam suatu analisis. Dalam penelitian ini uji konsistensi data dilakukan pada data hujan stasiun Petapahan Baru dan data debit stasiun AWLR Tandun dengan metode RAPS (Rescaled Adjusted Partial Sums) yaitu dengan membandingkan nilai $\mathrm{R}$ dan $\mathrm{Q}$ yang dihitung dengan nilai $\mathrm{R}$ dan Q kritik. Nilai kritik R dan Q terdapat pada Tabel $1[6]$.

Tabel 1. Nilai Kritik R dan Q

\begin{tabular}{ccccccc}
\hline \multirow{2}{*}{$\mathbf{N}$} & \multicolumn{3}{c}{$\mathbf{Q} / \mathbf{n}^{\mathbf{0 , 5}}$} & \multicolumn{3}{c}{$\mathbf{R} / \mathbf{n}^{\mathbf{0 , 5}}$} \\
\cline { 2 - 7 } & $\mathbf{9 0 \%}$ & $\mathbf{9 5 \%}$ & $\mathbf{9 9 \%}$ & $\mathbf{9 0 \%}$ & $\mathbf{9 5 \%}$ & $\mathbf{9 9 \%}$ \\
\hline \hline 10 & 1,05 & 1,14 & 1,29 & 1,21 & 1,28 & 1,38 \\
20 & 1,10 & 1,22 & 1,42 & 1,34 & 1,43 & 1,60 \\
30 & 1,12 & 1,24 & 1,46 & 1,40 & 1,50 & 1,70 \\
40 & 1,13 & 1,26 & 1,50 & 1,42 & 1,53 & 1,74
\end{tabular}

\begin{tabular}{ccccccc}
50 & 1,14 & 1,27 & 1,52 & 1,44 & 1,55 & 1,78 \\
100 & 1,17 & 1,29 & 1,55 & 1,50 & 1,62 & 1,86 \\
$\infty$ & 1,22 & 1,36 & 1,63 & 1,62 & 1,75 & 2,00 \\
\hline
\end{tabular}

Perhitungan uji konsistensi data hujan adalah sebagai berikut:

Tabel 2. Uji Konsistensi Data Hujan Stasiun Petapahan Baru

\begin{tabular}{ccccc}
\hline Tahun & $\mathrm{R}_{\text {tahunan }}$ & $\mathrm{R}_{\mathrm{i}}-\mathrm{R}_{\text {rerata }}$ & $\mathrm{Sk}^{*}$ & $\mathrm{Sk}^{* *}$ \\
\hline 2007 & 3819,0 & 295,81 & 295,81 & 0,262 \\
2008 & 3780,2 & 257,01 & 552,82 & 0,490 \\
2009 & 3995,7 & 472,51 & $1.025,33$ & 0,909 \\
2010 & 5291,2 & $1.768,05$ & $2.793,38$ & 2,477 \\
2011 & 1845,0 & $-1.678,22$ & $1.115,16$ & 0,989 \\
\hline Tahun & $\mathrm{R}_{\text {tahunan }}$ & $\mathrm{R}_{\mathrm{i}}-\mathrm{R}_{\text {rerata }}$ & $\mathrm{Sk}^{*}$ & $\mathrm{Sk}^{* *}$ \\
\hline 2012 & 2739,3 & $-783,89$ & 331,26 & 0,294 \\
2013 & 2069,9 & $-1.453,29$ & $-1.122,03$ & $-0,995$ \\
2014 & 2955,3 & $-567,89$ & $-1.689,92$ & $-1,499$ \\
2015 & 3799,7 & 276,51 & $-1.413,41$ & $-1,254$ \\
2016 & 4936,6 & $1.413,41$ & 0,00 & 0,000 \\
\hline
\end{tabular}

a. Kolom kedua menunjukkan jumlah hujan tiap tahun pada stasiun Petapahan Baru.

b. $R_{\text {rerata }}=3523,191 \mathrm{~mm}$.

c. Menghitung nilai standar deviasi $\left(D_{R}\right)$ : $\mathrm{D}_{\mathrm{R}}=\sqrt{\frac{\sum\left(\mathrm{R}_{\text {tahunan }}-\mathrm{R}_{\text {rerata }}\right)^{2}}{(\mathrm{n})}}=1127,557 \mathrm{~mm}$

d. Menghitung $\mathrm{Sk}^{*}$ dan $\mathrm{Sk}^{* *}$ :

$$
\begin{aligned}
& \mathrm{Sk}^{*}=\sum_{\mathrm{i}=1}^{\mathrm{k}}\left(\mathrm{R}_{\mathrm{i}}-\mathrm{R}_{\text {rerata }}\right)=295,809 \\
& \mathrm{Sk}^{* *}=\frac{\mathrm{Sk}^{*}}{\mathrm{D}}=0,262
\end{aligned}
$$

e. Menghitung nilai $\mathrm{Q}$ :

$$
\mathrm{Q}=\max _{0 \leq \mathrm{k} \leq \mathrm{n}}|\mathrm{Sk} * *|=2,477
$$

f. Menghitung nilai $\mathrm{R}$ :

$\mathrm{Ri}=\max _{0 \leq \mathrm{k} \leq \mathrm{n}}\left|\mathrm{Sk}^{* *}\right|-\min _{0 \leq \mathrm{k} \leq \mathrm{n}}\left|\mathrm{Sk}^{* *}\right|=3,97$

g. Nilai $Q$ dan $R$ dibandingkan dengan nilai kritik $\mathrm{Q}$ dan $\mathrm{R}$ dari Tabel 1 dengan kepercayaan $95 \%$ maka:

$$
\begin{aligned}
& \mathrm{Q}_{\text {hitung }}=\frac{\mathrm{Q}}{\sqrt{\mathrm{n}}}=\frac{2,477}{\sqrt{10}}=0,783 \\
& \mathrm{Q}_{\text {hitung }}<\mathrm{Q}_{\text {kritik }}=0,783<1,140 \\
& \mathrm{R}_{\text {hitung }}=\frac{\mathrm{R}}{\sqrt{\mathrm{n}}}=\frac{3,976}{\sqrt{10}}=1,257 \\
& \mathrm{R}_{\text {hitung }}<\mathrm{R}_{\text {kritik }}=1,257<1,280
\end{aligned}
$$

Berdasarkan perhitungan di atas data hujan stasiun Petapahan Baru dinyatakan panggah dan dapat digunakan dalam analisis.

Perhitungan uji konsistensi data debit adalah sebagai berikut: 
Tabel 3. Uji Konsistensi Data Debit Stasiun AWLR Tandun

\begin{tabular}{ccccc}
\hline Tahun & $\mathrm{R}_{\text {tahunan }}$ & $\mathrm{R}_{\mathrm{i}}-\mathrm{R}_{\text {rerata }}$ & $\mathrm{Sk}^{*}$ & $\mathrm{Sk}^{* *}$ \\
\hline 2007 & 4,263 & $-1,342$ & $-1,342$ & $-0,795$ \\
2008 & 4,211 & $-1,394$ & $-2,735$ & $-1,620$ \\
2009 & 8,565 & 2,961 & 0,225 & 0,133 \\
2010 & 4,383 & $-1,222$ & $-0,996$ & $-0,590$ \\
2011 & 4,124 & $-1,481$ & $-2,477$ & $-1,467$ \\
2012 & 4,580 & $-1,024$ & $-3,502$ & $-2,074$ \\
2013 & 5,690 & 0,085 & $-3,416$ & $-2,024$ \\
2014 & 6,514 & 0,909 & $-2,508$ & $-1,485$ \\
2015 & 8,347 & 2,742 & 0,235 & 0,139 \\
2016 & 5,370 & $-0,235$ & 0,000 & 0,000 \\
\hline
\end{tabular}

a. Kolom kedua menunjukkan rerata debit tiap tahun pada stasiun AWLR Tandun.

b. $Q_{\text {rerata }}=5,605 \mathrm{~m}^{3} /$ detik.

c. Menghitung nilai standar deviasi $\left(\mathrm{D}_{\mathrm{Q}}\right)$ :

$$
\mathrm{D}_{\mathrm{Q}}=\sqrt{\frac{\sum\left(\mathrm{Q}_{\text {tahunan }}-\mathrm{Q}_{\text {rerata }}\right)^{2}}{(\mathrm{n})}}=1,688 \mathrm{~m}^{3} / \text { detik }
$$

d. Menghitung Sk* dan Sk**:

$$
\begin{aligned}
& \mathrm{Sk}^{*}=\sum_{\mathrm{i}=1}^{\mathrm{k}}\left(\mathrm{R}_{\mathrm{i}}-\mathrm{R}_{\text {rerata }}\right)=-1,342 \\
& \mathrm{Sk}^{* *}=\frac{\mathrm{Sk}^{*}}{\mathrm{D}}=-0,795
\end{aligned}
$$

e. Menghitung nilai $\mathrm{Q}$ :

$$
\mathrm{Q}=\max _{0 \leq \mathrm{k} \leq \mathrm{n}}\left|\mathrm{Sk}^{* *}\right|=0,139
$$

f. Menghitung nilai $\mathrm{R}$ :

$\mathrm{Ri}=\max _{0 \leq \mathrm{k} \leq \mathrm{n}}\left|\mathrm{Sk}^{* *}\right|-\min _{0 \leq \mathrm{k} \leq \mathrm{n}}\left|\mathrm{Sk}^{* *}\right|=2,21$

g. Nilai $Q$ dan $R$ dibandingkan dengan nilai kritik $\mathrm{Q}$ dan $\mathrm{R}$ dari Tabel 1 dengan kepercayaan $95 \%$ maka:

$$
\begin{gathered}
\mathrm{Q}_{\text {hitung }}=\frac{\mathrm{Q}}{\sqrt{\mathrm{n}}}=\frac{0,139}{\sqrt{10}}=0,044 \\
\mathrm{Q}_{\text {hitung }}<\mathrm{Q}_{\text {kritik }}=0,044<1,140 \\
\mathrm{R}_{\text {hitung }}=\frac{\mathrm{R}}{\sqrt{\mathrm{n}}}=\frac{2,21}{\sqrt{10}}=0,70 \\
\mathrm{R}_{\text {hitung }}<\mathrm{R}_{\text {kritik }}=0,70<1,280
\end{gathered}
$$

Berdasarkan perhitungan uji konsistensi data di atas data debit stasiun AWLR Tandun dinyatakan panggah dan dapat digunakan dalam analisis.

Sebelum melakukan running model tangki (tank Model) Sugawara dilakukan persiapan data-data masukan (input) model. Data hujan dan klimatologi dalam satuan $\mathrm{mm} /$ hari sedangkan data debit dalam satuan $\mathrm{m}^{3} / \mathrm{dt}$. Namun, untuk data evapotranspirasi potensial dihitung menggunakan data klimatologi stasiun Pekanbaru dan berdasarkan metode Penmann Monteith [7] :

$\mathrm{ET}_{0}=\frac{0,408 \Delta \mathrm{Rn}+\gamma \frac{900}{(\mathrm{~T}+273)} \mathrm{U} 2 \text { (es-ea) }}{\Delta+\gamma(1+0,34 \mathrm{U} 2)}$

dengan:

$\mathrm{ET}_{0}=$ evapotranspirasi tanaman acuan ( $\left.\mathrm{mm} / \mathrm{hari}\right)$

$\mathrm{Rn}=$ radiasi matahari netto di atas permukaan tanaman (MJ/m2/hari)

$\mathrm{T}=$ suhu udara rata-rata $\left({ }^{\circ} \mathrm{C}\right)$

$\mathrm{U}_{2}=$ kecepatan angin pada ketinggian $2 \mathrm{~m}$ di atas permukaan tanah $(\mathrm{m} / \mathrm{det})$

es $=$ tekanan uap air jenuh $(\mathrm{kPa})$

ea $=$ tekanan uap air aktual $(\mathrm{kPa})$

$\Delta=$ kemiringan kurva tekanan uap air terhadap suhu $\left(\mathrm{kPa} /{ }^{\circ} \mathrm{C}\right)$

$\gamma=$ konstanta psikometrik $\left(\mathrm{kPa} /{ }^{\circ} \mathrm{C}\right)$

Hasil analisis evapotranspirasi potensial metode Penman-Monteith ditunjukkan pada Tabel 4.

Tabel 4. Hasil ET $\mathrm{ET}_{0}$ Metode Penman-Monteith

\begin{tabular}{cccccc}
\hline Bulan & J & $\begin{array}{c}\text { Suhu } \\
\text { Udara } \\
\left({ }^{\circ} \mathrm{C}\right)\end{array}$ & $\begin{array}{c}\text { Kec. } \\
\text { Angin } \\
(\mathrm{km} / \mathrm{hari})\end{array}$ & $\begin{array}{c}\text { RH } \\
(\%)\end{array}$ & $\begin{array}{c}\mathrm{n} / \mathrm{N} \\
(\%)\end{array}$ \\
\hline Jan & 15 & 27,66 & 22,80 & 85,20 & 37,26 \\
Feb & 45 & 28,13 & 23,99 & 83,55 & 41,37 \\
Maret & 76 & 30,37 & 26,00 & 84,30 & 36,78 \\
Apr & 106 & 28,45 & 26,94 & 84,35 & 38,99 \\
Mei & 136 & 28,56 & 24,65 & 83,75 & 43,95 \\
Jun & 167 & 28,60 & 25,85 & 82,70 & 48,66 \\
Jul & 197 & 28,32 & 23,62 & 83,00 & 43,24 \\
Aug & 228 & 28,71 & 27,16 & 84,20 & 50,09 \\
Sept & 258 & 27,53 & 24,65 & 81,15 & 36,09 \\
Okt & 288 & 28,03 & 27,49 & 81,90 & 39,75 \\
Nov & 319 & 26,72 & 25,41 & 84,75 & 39,17 \\
Des & 349 & 27,72 & 23,98 & 82,25 & 38,96 \\
\hline
\end{tabular}

Tabel 5. Hasil ET 0 Metode Penman-Monteith (lanjutan)

\begin{tabular}{ccccc}
\hline Bulan & $\begin{array}{c}\mathrm{es} \\
(\mathrm{kPa})\end{array}$ & $\begin{array}{c}\Delta \\
\left(\mathrm{kPa} /{ }^{\circ} \mathrm{C}\right)\end{array}$ & $\lambda(\mathrm{MJ} / \mathrm{Kg})$ & $\begin{array}{c}\gamma \\
\left(\mathrm{kPa} /{ }^{\circ}\right. \\
\mathrm{C})\end{array}$ \\
\hline Jan & 3,71 & 0,22 & 2,44 & 0,07 \\
Feb & 3,81 & 0,22 & 2,43 & 0,07 \\
Maret & 4,33 & 0,25 & 2,43 & 0,07 \\
Apr & 3,88 & 0,23 & 2,43 & 0,07 \\
Mei & 3,91 & 0,23 & 2,43 & 0,07
\end{tabular}




\begin{tabular}{ccccc} 
Jun & 3,92 & 0,23 & 2,43 & 0,07 \\
Jul & 3,85 & 0,22 & 2,43 & 0,07 \\
Aug & 3,94 & 0,23 & 2,43 & 0,07 \\
Sept & 3,68 & 0,21 & 2,44 & 0,07 \\
Okt & 3,79 & 0,22 & 2,43 & 0,07 \\
Nov & 3,51 & 0,21 & 2,44 & 0,07 \\
Des & 3,72 & 0,22 & 2,44 & 0,07 \\
\hline
\end{tabular}

Tabel 6. Hasil $\mathrm{ET}_{0}$ Metode Penman-Monteith (lanjutan)

\begin{tabular}{ccccc}
\hline Bulan & $\varepsilon^{\prime}$ & $\mathrm{f}$ & $\delta(\mathrm{rad})$ & $\mathrm{dr}$ \\
\hline Jan & 0,18 & 0,44 & $-0,37$ & 1,03 \\
Feb & 0,18 & 0,47 & $-0,24$ & 1,02 \\
Mar & 0,19 & 0,43 & $-0,03$ & 1,01 \\
Apr & 0,18 & 0,45 & 0,17 & 0,99 \\
Mei & 0,18 & 0,50 & 0,33 & 0,98 \\
Jun & 0,18 & 0,54 & 0,41 & 0,97 \\
Jul & 0,18 & 0,49 & 0,37 & 0,97 \\
Aug & 0,18 & 0,55 & 0,23 & 0,98 \\
Sept & 0,17 & 0,42 & 0,04 & 0,99 \\
Okt & 0,18 & 0,46 & $-0,17$ & 1,01 \\
Nov & 0,17 & 0,45 & $-0,33$ & 1,02 \\
Des & 0,17 & 0,45 & $-0,41$ & 1,03 \\
\hline
\end{tabular}

Tabel 7. Hasil ET $\mathrm{ET}_{0}$ Metode Penman-Monteith (lanjutan)

\begin{tabular}{ccccc}
\hline Bulan & $\begin{array}{c}\text { Ra } \\
(\mathrm{MJ} / \mathrm{m} 2 / \text { hari })\end{array}$ & Rs & Rns & Rnl \\
\hline Jan & 36,44 & 15,90 & 12,24 & 3,10 \\
Feb & 37,59 & 17,17 & 13,22 & 3,40 \\
Mar & 37,92 & 16,45 & 12,67 & 3,43 \\
Apr & 36,61 & 16,29 & 12,54 & 3,31 \\
Mei & 34,49 & 16,20 & 12,47 & 3,64 \\
Jun & 33,14 & 16,35 & 12,59 & 3,93 \\
Jul & 33,64 & 15,68 & 12,08 & 3,54 \\
Aug & 35,54 & 17,79 & 13,70 & 4,08 \\
Sept & 37,20 & 16,02 & 12,33 & 2,94 \\
Okt & 37,49 & 16,82 & 12,95 & 3,25 \\
Nov & 36,59 & 16,31 & 12,56 & 3,09 \\
Des & 35,92 & 15,98 & 12,30 & 3,17 \\
\hline
\end{tabular}

Tabel 8. Hasil ET $\mathrm{ET}_{0}$ Metode Penman-Monteith (lanjutan)

\begin{tabular}{ccccc}
\hline Bulan & Rn & $\begin{array}{c}\mathrm{U} 2 \\
(\mathrm{~m} / \mathrm{dt})\end{array}$ & $\begin{array}{c}\mathrm{ET}_{0} \\
(\mathrm{~mm} / \\
\text { hari })\end{array}$ & $\begin{array}{c}\mathrm{ET}_{0} \\
(\mathrm{~mm} / \mathrm{bln})\end{array}$ \\
\hline Jan & 9,14 & 0,36 & 2,88 & 89,31 \\
Feb & 9,82 & 0,38 & 3,12 & 87,39 \\
Mar & 9,24 & 0,41 & 3,02 & 93,75
\end{tabular}

\begin{tabular}{ccccc} 
Apr & 9,24 & 0,43 & 2,95 & 88,63 \\
Mei & 8,83 & 0,39 & 2,83 & 87,88 \\
Jun & 8,65 & 0,41 & 2,79 & 83,76 \\
Jul & 8,54 & 0,37 & 2,74 & 84,87 \\
Aug & 9,61 & 0,43 & 3,08 & 95,54 \\
Sept & 9,39 & 0,39 & 2,99 & 89,57 \\
Okt & 9,70 & 0,43 & 3,10 & 96,16 \\
Nov & 9,47 & 0,40 & 2,95 & 88,56 \\
Des & 9,14 & 0,38 & 2,91 & 90,10 \\
\hline
\end{tabular}

Selanjutnya adalah analisis hujan-debit menggunakan model konseptual. Penelitian ini menggunakan Tank Model dengan 4 (empat) tangki disusun secara vertikal atau seri. Curah hujan $(R)$ yang jatuh ke permukaan tanah akan mengisi tangki paling atas. Air yang tertampung oleh tangki 1 dipengaruhi evapotranspirasi mengalir lewat lubang-lubang di dinding kanan atau merembes lewat lubang di dasar tangki dan masuk mengisi tangki 2. Proses ini berulang hingga sampai tangki terakhir. Jumlah limpasan yang keluar dari lubang-lubang di dinding kanan semua tangki adalah merupakan besarnya limpasan yang dihitung dalam suatu daerah pengaliran dengan masukan curah hujan tertentu. Jadi dengan melihat tangki-tangki dalam model dan membandingkan dengan komponen limpasan maka tangki 1 yang terletak paling atas kira-kira merupakan limpasan permukaan, tangki 2 merupakan limpasan antara (intermediate flow) sedangkan tangki 3 dan tangki 4 merupakan aliran dasar (base flow).

Dari 4 (empat) susunan tangki tersebut terdapat parameter-parameter model sebanyak 24 parameter. Masing-masing tangki memiliki 6 (enam) parameter model yang terdiri dari tinggi tangki $(H i)$, kedalaman dua lubang samping $\left(h_{1 i}\right.$ dan $\left.h_{2 i}\right)$, koefisien dua lubang samping $\left(f_{1 i} \operatorname{dan} f_{2 i}\right)$ dan koefisien lubang dasar tangki $(b)$.

Guna memperoleh besaran parameter model maka dilakukan tahapan kalibrasi model. Kalibrasi merupakan tahap menyesuaikan atau mengoptimalkan nilai parameter model yang dapat dikatakan berhasil jika nilai parameter telah memenuhi nilai evaluasi yang ditentukan. Penelitian ini menggunakan kalibrasi metode trial and error.

Pada tahap kalibrasi data yang digunakan untuk kalibrasi adalah 3 tahun mulai tahun 20072009 dan untuk verifikasi yaitu 7 tahun mulai tahun 2010-2016. Berdasarkan kalibrasi diperoleh parameter model untuk keluaran (output) terbaik sebagai berikut.

Tabel 9. Parameter Tank Model (mm)

\begin{tabular}{ccccc}
\hline Parameter & Tank 1 & Tank 2 & Tank 3 & Tank 4 \\
\hline$H_{i}$ & 400 & 100 & 50 & 50
\end{tabular}

Fachrunnisa, Perbandingan Debit Andalan Hasil Tank Model Terhadap Debit Pengamatan Sungai Tapung Kiri Stasiun Tandun 


\begin{tabular}{ccccc}
$h_{i 2}$ & 350 & 90 & 20 & 20 \\
$f_{i 2}$ & 0,20 & 0,009 & 0,05 & 0,05 \\
$h_{i 1}$ & 50 & 50 & 50 & 50 \\
$f_{i 1}$ & 0,13 & 0,0004 & 0,006 & 0,001 \\
$b_{i}$ & 0,60 & 0,01 & 0,65 & 0,85 \\
\hline
\end{tabular}

Berdasarkan parameter optimum tersebut diperoleh debit simulasi bulanan hasil keluaran Tank Model. Hubungan debit hasil keluaran model $\left(\mathrm{Q}_{\text {sim }}\right)$, debit observasi $\left(\mathrm{Q}_{\mathrm{obs}}\right)$ dan hujan dapat dilihat pada Gambar 3.

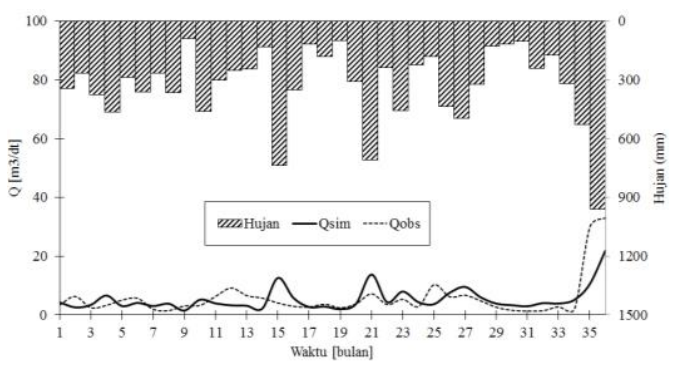

Gambar 3. Hidrograf Hujan, $\mathrm{Q}_{\text {sim }}$ dan $\mathrm{Q}_{\mathrm{obs}}$ Tahap Kalibrasi

Hasil kalibrasi model menunjukkan adanya kesamaan pola antara keluaran model dan debit pengamatan. Namun, masih terdapat nilai-nilai keluaran model yang bersifat over estimate maupun under estimate.

Berdasarkan hasil keluaran Tank Model maka langkah selanjutnya adalah menghitung debit andalan. Evaluasi terbaik model diperoleh untuk pembagian data kalibrasi selama 3 tahun (2007-2009) dan verifikasi 7 tahun (2010-2016). Debit hasil verifikasi model dianalisis sebagai debit andalan dan dihitung perbandingannya terhadap debit pengamatan. Keluran tank model pada tahap verifikasi ditampilkan pada Tabel 10 .

Tabel 10. Debit Tank Model ( $\left.\mathrm{m}^{3} / \mathrm{dt}\right)$

\begin{tabular}{crrrrrl}
\hline Tahun & Jan & Feb & Mar & Apr & Mei & Jun \\
\hline 2010 & 6,17 & 5,23 & 3,37 & 3,53 & 2,18 & 3,25 \\
2011 & 3,19 & 4,11 & 6,26 & 5,79 & 4,99 & 3,11 \\
2012 & 2,88 & 7,36 & 2,19 & 5,23 & 3,64 & 1,52 \\
2013 & 4,68 & 6,66 & 5,47 & 7,56 & 5,97 & 4,69 \\
2014 & 5,69 & 6,32 & 4,85 & 5,82 & 6,75 & 5,54 \\
2015 & 7,77 & 8,16 & 9,00 & 8,76 & 9,04 & 9,33 \\
2016 & 8,86 & 6,34 & 6,62 & 6,66 & 7,30 & 6,45 \\
\hline Tahun & Jul & Agus & Sep & Okt & Nov & Des \\
\hline 2010 & 2,80 & 4,92 & 9,11 & 3,63 & 5,34 & 3,08 \\
2011 & 1,33 & 2,77 & 2,99 & 3,68 & 5,14 & 6,11
\end{tabular}

\begin{tabular}{rrrrrrr}
2012 & 2,58 & 2,35 & 3,19 & 4,34 & 6,32 & 13,36 \\
2013 & 3,87 & 7,68 & 5,30 & 5,71 & 5,32 & 5,36 \\
2014 & 6,71 & 7,61 & 8,14 & 5,29 & 8,40 & 7,04 \\
2015 & 9,48 & 6,70 & 4,30 & 3,56 & 8,52 & 15,55 \\
2016 & 5,46 & 4,23 & 3,14 & 2,99 & 2,81 & 3,58 \\
\hline
\end{tabular}

Sebagaimana teori tentang peluang teoritis metode Weibull maka besaran debit harus diurutkan dari nilai terbesar ke nilai terkecil (lihat Tabel 11).

Tabel 11. Data Debit Urutan Besar ke Kecil (m²/detik)

\begin{tabular}{crrrrrr}
\hline $\begin{array}{c}\text { No. } \\
\text { Urut } \\
\text { Data }\end{array}$ & Jan & Feb & Mar & Apr & Mei & Jun \\
\hline 1 & 12,25 & 14,64 & 16,51 & 19,99 & 13,25 & 11,98 \\
2 & 10,60 & 10,61 & 13,74 & 17,43 & 13,18 & 9,73 \\
3 & 10,45 & 10,59 & 10,08 & 16,96 & 12,25 & 9,49 \\
4 & 9,21 & 10,26 & 9,45 & 10,30 & 9,65 & 9,35 \\
5 & 8,66 & 9,14 & 8,96 & 9,83 & 9,22 & 8,89 \\
6 & 8,53 & 8,81 & 8,85 & 9,26 & 8,73 & 8,64 \\
7 & 8,03 & 8,31 & 8,63 & 9,06 & 8,12 & 8,37 \\
\hline No. & & & & & & \\
Urut & Jul & Agus & Sep & Okt & Nov & Des \\
Data & & & & & & \\
\hline 1 & 20,14 & 18,32 & 14,10 & 18,35 & 20,97 & 15,27 \\
2 & 10,45 & 10,73 & 13,41 & 10,26 & 19,62 & 11,18 \\
3 & 9,19 & 10,21 & 12,61 & 10,10 & 14,27 & 10,82 \\
4 & 8,99 & 8,28 & 10,46 & 9,13 & 10,27 & 9,83 \\
5 & 8,32 & 8,20 & 8,51 & 9,10 & 9,44 & 9,56 \\
6 & 8,27 & 8,01 & 8,32 & 8,71 & 9,25 & 9,09 \\
7 & 7,82 & 7,74 & 7,90 & 7,78 & 8,86 & 8,54 \\
\hline
\end{tabular}

Setelah data debit diurutkan maka selanjutnya adalah menghitung dengan cara interpolasi, debit sesuai probabilitas $\mathrm{Q}_{20 \%}, \mathrm{Q}_{50 \%}$ dan $\mathrm{Q}_{80 \%}$ sebagaimana Tabel 12.

Tabel 12. Probabilitas Debit ( $\left.\mathrm{m}^{3} / \mathrm{detik}\right)$

\begin{tabular}{rrrrrrr}
\hline Prob. & \multicolumn{1}{c}{ Jan } & \multicolumn{1}{c}{ Feb } & \multicolumn{1}{c}{ Mar } & \multicolumn{1}{c}{ Apr } & Mei & \multicolumn{1}{c}{ Jun } \\
\hline $20 \%$ & 11,26 & 12,22 & 14,85 & 18,45 & 13,21 & 10,63 \\
$50 \%$ & 9,21 & 10,26 & 9,45 & 10,30 & 9,65 & 9,35 \\
$80 \%$ & 8,33 & 8,61 & 8,76 & 9,18 & 8,48 & 8,53 \\
$90 \%$ & 7,92 & 8,21 & 8,58 & 9,02 & 8,00 & 8,32 \\
$95 \%$ & 7,72 & 8,01 & 8,49 & 8,95 & 7,76 & 8,21 \\
\hline Prob. & Jul & Agus & Sep & Okt & Nov & Des \\
\hline $20 \%$ & 14,32 & 13,77 & 13,69 & 13,50 & 20,16 & 12,81 \\
$50 \%$ & 8,99 & 8,28 & 10,46 & 9,13 & 10,27 & 9,83 \\
$80 \%$ & 8,09 & 7,90 & 8,15 & 8,34 & 9,09 & 8,87
\end{tabular}




\begin{tabular}{lllllll}
$90 \%$ & 7,73 & 7,68 & 7,82 & 7,59 & 8,79 & 8,43 \\
$95 \%$ & 7,55 & 7,57 & 7,65 & 7,22 & 8,63 & 8,21 \\
\hline
\end{tabular}

Selanjutnya menggambarkan debit andalan pada tabel di atas kedalam bentuk kurva durasi debit. Kurva durasi debit merupakan distribusi debit andalan yang menunjukkan hubungan antara debit dan probabilitas kejadian. Pada gambar dapat dilihat kurva mengalami penurunan hal ini disebabkan apabila nilai atau besaran debit kecil maka probabilitas kejadian di lapangan besar, begitu juga sebaliknya apabila nilai atau besaran debit besar maka probabilitas kejadian di lapangan kecil. Kurva durasi debit ditampilkan sebagaimana gambar-gambar berikut.

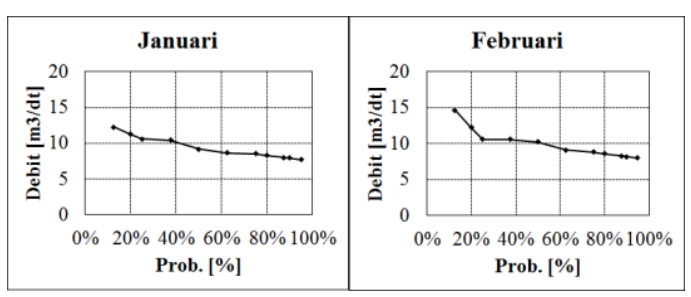

Gambar 4. Kurva Durasi Debit Bulan Januari dan Februari

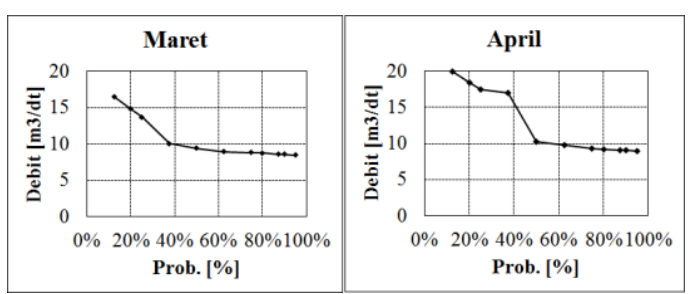

Gambar 5. Kurva Durasi Debit Bulan Maret dan April

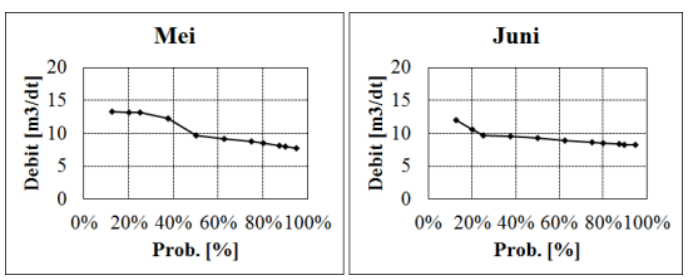

Gambar 6. Kurva Durasi Debit Bulan Mei dan Juni

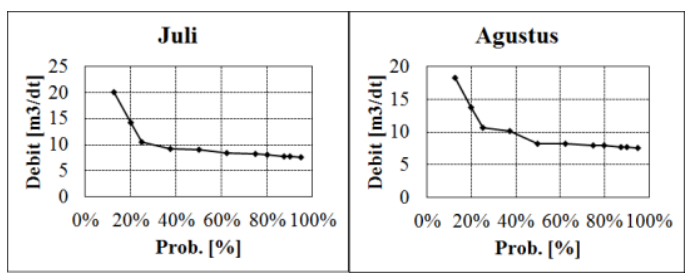

Gambar 7. Kurva Durasi Debit Bulan Juli dan Agustus

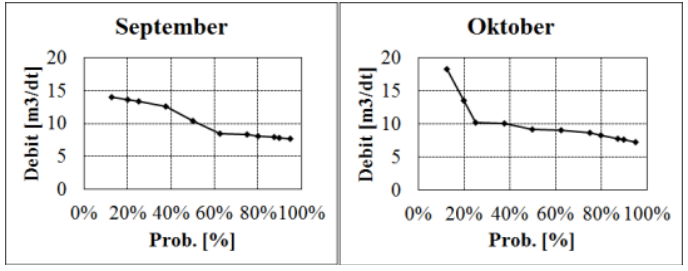

Gambar 8. Kurva Durasi Debit Bulan September dan Oktober

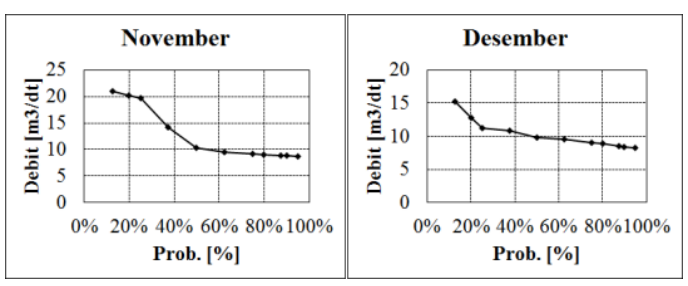

Gambar 9. Kurva Durasi Debit Bulan November dan Desember

Sedangkan debit andalan berdasarkan data pengamatan stasiun AWLR Tandun ditunjukkan pada Tabel 13.

Tabel 13. Debit Andalan Stasiun Tandun ( $\left.\mathrm{m}^{3} / \mathrm{detik}\right)$

\begin{tabular}{ccccccc}
\hline Prob. & Jan & Feb & Mar & Apr & Mei & Jun \\
\hline $20 \%$ & 8,20 & 7,68 & 7,57 & 8,04 & 8,00 & 7,60 \\
$50 \%$ & 5,69 & 6,34 & 5,47 & 5,82 & 5,97 & 4,69 \\
$80 \%$ & 3,07 & 4,78 & 2,89 & 4,55 & 3,05 & 2,47 \\
$90 \%$ & 2,82 & 3,89 & 1,95 & 3,19 & 1,89 & 1,21 \\
$95 \%$ & 2,70 & 3,44 & 1,48 & 2,51 & 1,31 & 0,57 \\
\hline Prob. & Jul & Agus & Sep & Okt & Nov & Des \\
\hline $20 \%$ & 7,82 & 7,64 & 8,53 & 5,46 & 8,45 & 14,24 \\
$50 \%$ & 3,87 & 4,92 & 4,30 & 3,68 & 5,34 & 6,11 \\
$80 \%$ & 2,08 & 2,60 & 3,08 & 3,33 & 4,21 & 3,38 \\
$90 \%$ & 1,07 & 2,27 & 2,96 & 2,87 & 2,34 & 2,98 \\
$95 \%$ & 0,57 & 2,10 & 2,90 & 2,64 & 1,41 & 2,78 \\
\hline
\end{tabular}

Secara umum analisis debit andalan dilakukan terhadap 3 kondisi yaitu kondisi basah $\left(\mathrm{Q}_{20 \%}\right)$, kondisi normal $\left(\mathrm{Q}_{50 \%}\right)$ dan kondisi kering $\left(\mathrm{Q}_{80 \%}\right)$. Diagram debit andalan hasil model dan pengamatan sebagaimana gambar berikut.

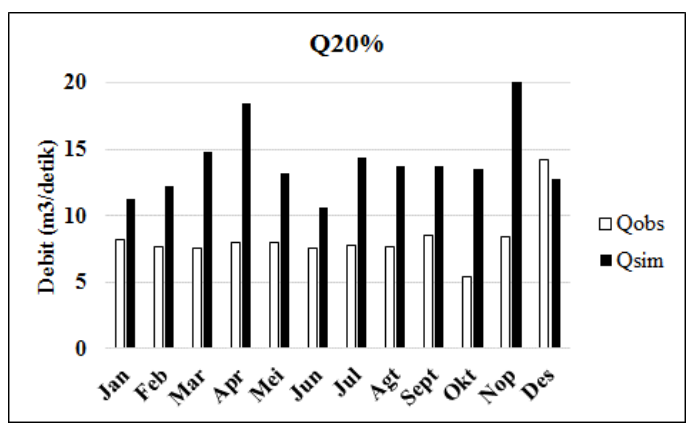

Gambar 10. Diagram Debit Andalan Keluaran Model dan Pengamatan Kondisi Basah (Q20\%) 


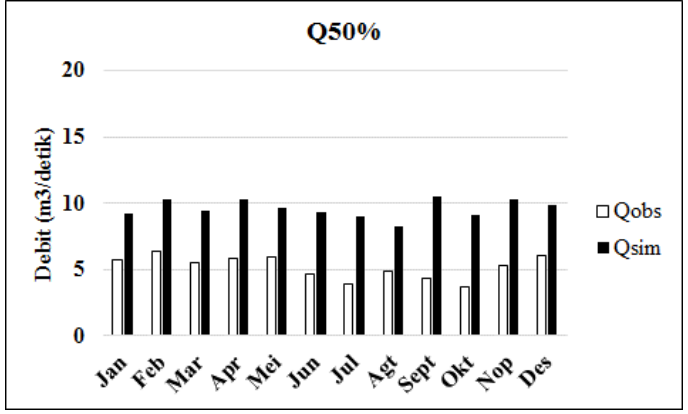

Gambar 11. Diagram Debit Andalan Keluaran Model dan Pengamatan Kondisi Normal (Q50\%)

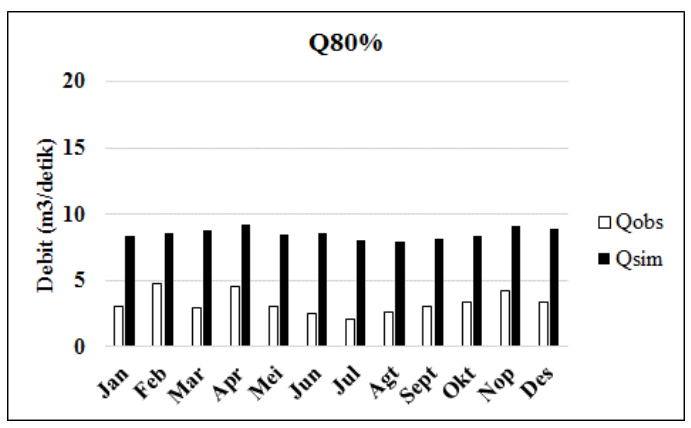

Gambar 12. Diagram Debit Andalan Keluaran Model dan Pengamatan Kondisi Kering $\left(Q_{80 \%}\right)$

Guna menilai kinerja tank model dilakukan perbandingan nilai hasil keluaran model dengan data pengamatan. Tolak ukur yang digunakan adalah nilai RMSE. Perhitungan dilakukan terhadap tiga kondisi yaitu kondisi basah (Q20\%), kondisi normal $\left(\mathrm{Q}_{50 \%}\right)$ dan kondisi kering $\left(\mathrm{Q}_{80 \%}\right)$. Untuk kondisi normal $\left(\mathrm{Q}_{20 \%}\right)$ yaitu:

RMSE $=\sqrt{\frac{\sum(\text { Qobs-Qsim })^{2}}{n}}=\sqrt{\frac{538,01}{12}}=\sqrt{44,83}=6,70$

Untuk kondisi normal (Q50\%) yaitu:

RMSE $=\sqrt{\frac{\sum(\text { Qobs-Qsim })^{2}}{n}}=\sqrt{\frac{242,04}{12}}=\sqrt{20,17}=4,49$

Untuk kondisi kering ( $\left.{ }_{80 \%}\right)$ yaitu:

RMSE $=\sqrt{\frac{\sum(\text { Qobs-Qsim })^{2}}{n}}=\sqrt{\frac{333,38}{12}}=\sqrt{27,78}=5,27$
Berdasarkan nilai RMSE untuk semua kondisi dapat dinyatakan bahwa Tank Model mampu memberikan nilai cukup baik guna menghasilkan debit andalan. Hal tersebut dibuktikan dengan nilai RMSE mendekati nol dan nilai tempatnya sama dengan nilai tempat data pengamatan.

\section{KESIMPULAN}

1. Analisis ketersediaan air Sungai Tapung Kiri tepatnya pada pos duga air Tandun dalam perbandingan debit simulasi hasil permodelan dengan debit observasi diperoleh nilai RMSE kondisi musim basah $\left(\mathrm{Q}_{20 \%}\right)=6,70$; kondisi normal $\left(\mathrm{Q}_{50 \%}\right)=4,49$ dan musim kering $\left(\mathrm{Q}_{80 \%}\right)=5,27$.

2. Berdasarkan nilai RMSE maka dapat dinyatakan bahwa Tank Model mampu memberikan nilai cukup baik guna menghasilkan debit andalan.

\section{DAFTAR PUSTAKA}

[1] R. P. Kesuma, A. H. Wahyudi, and Suyanto, "Aplikasi Metode Mock, Nreca, Tank Model, dan Rainrun Di Bendung Trani, Wonotoro, Sudangan, dan Walikan," Matriks Tek. Sipil, Vol. 1, No. 4, pp. 472-479, 2013.

[2] B. I. Setiawan, "Optimasi Parameter Tank Model,” vol. 17, No. 1, 2003.

[3] Song JH, Her Younggu, Park J., Kang MS., "Exploring Parsimonious Daily Rainfal-Runoff Model Structure Using The Hyperbolic Tangent Function and Tank Model, Journal of Hydrology, Vol. 574, page 574-587, 2019

[4] Fauzi M., Malik A., and D. A. Putra, "Application of Hybrid-Ihacres models for water availability in Siak River," vol. 4017, 2019.

[5] Kodoatie, Robert J dan Sjarief, Roestam. 2010. “Tata Ruang Air". Yogyakarta : Penerbit Andi 
[6] Harto, S. 1993. Analisis Hidrologi. Jakarta : PT. Gramedia Pustaka Utama.

[7] SNI 7745, "Tata cara penghitungan evapotranspirasi tanaman acuan dengan metode Penman-Monteith,” 2012. 